\title{
Population dynamics of the bat Dermanura tolteca (Chiroptera: Phyllostomidae) in a tropical forest in Mexico
}

\author{
José Luís García-García, Antonio Santos-Moreno \& Arisbe Rodríguez-Alamilla \\ Laboratorio de Ecología Animal. Centro Interdisciplinario de Investigación para el Desarrollo Integral Regional, \\ Unidad Oaxaca, IPN. Calle Hornos 1003, Sta. Cruz Xoxocotlán, Oaxaca, México. C. P. 71230; \\ reylagarto_jl@hotmail.com, asantosm90@hotmail.com, aris_en_@hotmail.com
}

Received 17-VIII-2009. Corrected 08-IV-2010. Accepted 12-V-2010.

\begin{abstract}
The fruit-eating bat, Dermanura tolteca, has a broad geographic distribution in Mexico and it is a very important seed dispersal of Neotropical plants. Nonetheless, information on the biology of this bat species is scarce, especially with regard to demography. We studied some ecological aspects and population dynamics of D. tolteca from Southeastern Mexican State of Oaxaca. The study was conducted in a perennial tropical forest, over a period of 80 nights, a sampling effort of 73200 mist-net-hour, from May 2006 to August 2007. A total of 176 specimens were captured, 98 females and 78 males. Population size was estimated in 237 individuals in the study area, with a greater number during rainy season. The population density of this bat, in its range of distribution in Mexico is low compared to other nose-leaf bats. Captures were correlated with monthly precipitation, and this result may be linked to food resources abundance in tropical and subtropical areas. The reproductive pattern was bimodal polyestrous, with birth periods between August-September and April-June. Greater body mass was observed in females than males. The male-female ratio and age-related demographics were similar to other noseleaf bats. The biological characteristics of $D$. tolteca are typical of nose-leaf bats of the family Phyllostomidae. Rev. Biol. Trop. 58 (4): 1323-1334. Epub 2010 December 01.
\end{abstract}

Key words: Phyllostomidae, population size, polyestrous, capture-recapture, bats, tropical rain forest, reproductive pattern.

The diversity of Neotropical bat species is primarily due to the species richness among the Phyllostomidae group, which includes the largest number of species, with diverse eating habits (Jones \& Carter 1976, Findley 1993). This family consists of 55 genera and 159 species (Simmons 2005), among which 55 have been recorded in Mexico (Ceballos et al. 2005a). Dermanura tolteca, is found from Western regions of Mexico (Sinaloa and Durango) and Eastern regions of the country (Nuevo León and Tamaulipas) to Panama, through Central America (Handley 1987).

Dermanura tolteca is associated with mountain cloud forests, as well as perennial and deciduous tropical forests (Watkins et al. 1972,
Iñiguez-Dávalos 1993). The perennial tropical forests of Mexico have a limited distribution, occupying only $11 \%$ of the country's territory (Rzedowski 1991, García-Mendoza 2004). This ecosystem is one of the most affected by agricultural-related deforestation, which accounts a disappearance of $90 \%$, at an annual rate of 630 000ha (Dirzo \& García 1992, Arriaga et al. 2000). Perennial tropical forest is readily noticeable due to its rich abundance of mammals (Medellín 1994, Espinoza-Medinilla et al. 1998, Briones-Salas \& Sánchez-Cordero 2004) and, particularly, the associated bats diversity, e.g., Vampyrum spectrum, Trachops cirrhosus, Tonatia sp., Mimon spp., Artibeus spp. and Dermanura spp. (Ceballos et al. 2005b). 
Despite its wide geographic distribution, Dermanura tolteca is not abundant in environments in which its presence has been previously documented in Mexico (Iñiguez-Dávalos 1993, Navarro \& León-Paniagua 1995, Stoner 2002, Briones-Salas et al. 2004, García-García $\&$ Santos-Moreno 2008). This species has been collected with mist nets in caves, below plantain leaves, and in tent-like shelters constructed with leaves from a variety of plants (Timm 1987, Kunz \& McCracken 1996, McCracken \& Wilkinson 2000); and in these roost sites, D. tolteca form small aggregations. This species has been classified as a generalist since is a fruit-eating species, but $D$. tolteca has also been considered to be a specialist when related to Cecropia (Webster \& Jones 1982). In Costa Rica, some field data indicate that D. tolteca feeds on Solanum spp., Eugenia acapulcensis, Ficus spp. and 14 other plants species (Dinerstein 1986).

The diversity and abundance of fruit-eating bats is of great ecological importance, since these species are seed dispersers of a wide variety of Neotropical plants, especially those typical of early successional stages (Morrison 1978, Fleming \& Heithaus 1981, Dinerstein 1986). It has been reported that 6 to 8 individuals/ha of Artibeus jamaicensis can transport, up to $7 \%$ of the annual fruit production of Ficus spp. in jungles, which represents an average of approximately 650kg (Morrison 1978).

In spite of the ecological importance of D. tolteca populations in regional and local ecosystems, the lack of demographic and ecological information is readily apparent and has changed with time. There is a need to analyze their current situation on age structure (adults, sub-adults and juveniles), male-female ratio, reproductive patterns, and population size. Those factors can be used to evaluate the effects associated with disturbance, roost sites loss, hibernation and maternity, as well as related mortality due to environmental contamination (Kunz 2003, O'Shea et al. 2004). Thus, the goals of this study are to estimate and document its population size, age structure, male-female ratio, reproductive pattern and body mass of $D$. tolteca in a tropical forest located in the State of Oaxaca, Southeastern Mexico.

\section{MATERIALS AND METHODS}

Study Area: The study area is in the municipality of Santiago Comaltepec, in the Northern region of Oaxaca State, Southeastern Mexico (1740'31.4" N-96¹9'25.1" W). With an elevation of $858 \mathrm{~m}$ above the sea level (a.s.1.), the dominant vegetation is perennial tropical forest (sensu Rzedowski 1978), with secondary vegetation characterized by abundant shrub and herbaceous species (SEMARNAP-INEGIUNAM 2000). This vegetation is transitional, between mountain cloud forest and lowland rain forest (Boyle 1996), and is characterized by a small proportion of epiphytic and palm species, with a broader vegetation structure than that in cloud forests (Rzedowski \& Palacios-Chávez 1977, Boyle 1996). The population density of woody species $(>2.5 \mathrm{~cm}$ of diameter at breast height, DBH) is 341 individuals/0.1ha, with an average DBH of $8.4 \mathrm{~cm}$ (Boyle 1996). The dominant plant species are included in the families: Araceae, Asteraceae, Cecropiaceae, Fabaceae, Lauraceae, Piperaceae and Moraceae (Boyle 1996). Despite the historical use of this area and the extensive deforestation in Southeastern Mexico, there is a moderate conservation state of the study area is remarkable (Dirzo \& Miranda 1991, Boyle 1996, Meave et al. 2006).

In order to evaluate the relationship between population parameters and environmental characteristics, climatic data on precipitation and temperature of a 10 years period (1982-1985 and 1991-1997), was obtained and analyzed (Servicio Meteorológico Nacional de México 2000). These data were recorded at the Campamento Vista Hermosa Meteorological Station $\left(96^{\circ} 10^{\prime} \mathrm{N}, 17^{\circ} 40^{\prime} \mathrm{W}\right)$, three kilometers South from the study area, at an elevation of 1 000m a.s.l. Data indicated that the dry season extended from December to May, with an average monthly rainfall of $225.53 \mathrm{~mm}(\mathrm{SD}=56.34)$ and an average monthly temperature of $16.66^{\circ} \mathrm{C}$ $(\mathrm{SD}=1.90)$. Besides, the rainy occurred from 
June to November, with a monthly average rainfall of $670.87 \mathrm{~mm}(\mathrm{SD}=110.14)$ and a monthly average temperature of $17.07^{\circ} \mathrm{C}(\mathrm{SD}=0.82)$.

Field data source: This study was conducted from May 2006 to August 2007, five nights per month, representing eighty nights of effective sampling. Samples were obtained during seven months of dry season (May-December 2006 and January-May 2007) and nine months of rainy season (June-November 2006 and June-August 2007). Data corresponding to each season were considered one sampling, regardless of the year. The specimens were captured with eight $6 \times 2.5 \mathrm{~m}$ mist nets, placed on trails at the same site for each monthly sampling. These nets were placed at 18:00h and removed at 03:00h the next day (eight hours of capture), resulting in a monthly sampling effort of $4800 \mathrm{~m}^{2} / \mathrm{h}$ (area of mist-nets cover per hour, Straube \& Bianconi 2002) and a total sampling effort of $73200 \mathrm{~m}^{2} / \mathrm{h}$.

When a specimen was captured for the first time, a nylon cable tie (STEREN®, model TY300, $100 \mathrm{~mm}$ long $\times 2.5 \mathrm{~mm}$ wide with a weight of $0.8 \mathrm{~g}$ ) was placed on the specimen as a necklace. This necklace includes a number that is engraved from 1 to 100 . When the number was greater than 100 , a perforation was made to represent hundreds. When adjusting such collars, care was taken to fit it around the neck of the animal to prevent collar loss, as well as any harm, or interference with its mobility.

For each captured specimen, we recorded sex and age (determined by the degree of ossification in the phalangeal epiphyses observed against light). The age categories were determined following the criteria proposed by Handley et al. (1991) for Artibeus jamaicensis: juveniles, adults and sub-adults. In order to determine reproductive condition, we followed the criteria of Handley et al. (1991) and Kunz et al. (1996): females were classified as non-reproductive and reproductive (pregnant, lactating and postlactating). Males were classified as reproductively active if they possessed scrotal testicles, as those that lacked such a condition were considered inactive. The weight was obtained using a scale with a capacity of $100 \mathrm{~g}$. The captured specimens were released in the same capture site, immediately after tagging.

The population size was estimated by using the direct enumeration method, which considers the minimum number of live individuals (MNA) (Krebs 1966), and the trappability as an estimator of the accuracy of these estimates (fraction of the population trapped) (Krebs \& Boonstra 1984). MNA is an appropriate method in situations with low number of recaptures (Krebs 1999), as in this study. The estimation of the MNA can be considered as the lower limit of population size (Mckelvey \& Pearson 2001). MNA method has been criticized because is subject to negative bias that is greatest at the beginning and end of the study and at least in the middle (Nichols \& Pollock 1983, Efford 1992), but the absolute value of the bias of enumeration estimates is smaller when capture probability or trappability is high (Adler et al. 1984, Nichols 1986, Pocock et al. 2004). In this study, from the 16 months sampled, 10 showed $75 \%$ or higher trappability of (see below). The relationship between the number of captures per month, and temperature and precipitation was evaluated using a simple linear regression, and a Spearman's rank correlation coefficient (Zar 1999).

The male-female ratio was expressed as the number of males per female. In order to assess significant differences in relation to a 1:1 ratio, a test based on binomial coefficients was employed (Zar 1999). The age classes were compared in pairs using a student t-test. A Mann-Whitney U-test (data no present normality) was applied to evaluate age differences between seasons. Reproductive activity was evaluated, using a student t-test, by first comparing the number of inactive females with those showing reproductive activity (lactating, pregnant or post-lactating) (Zar 1999). The correlation of reproductive activity (number of monthly captures of males and females with some reproductive activity) with precipitation and temperature was measured 
using a Spearman's rank correlation coefficient. Spearmn rank correlation coefficient was used because neither number of captures, nor precipitation or temperature showed a normal distribution (Fig. 1) (Zar 1999).

The variation in body mass (in grams) was evaluated, excluding to pregnant female from analysis. A Kruskal-Wallis one-way analysis of variance (data no present normality) was used to evaluate variation in physical condition between seasons (Zar 1999), and body mass correlation was evaluated during the two seasons with average monthly temperature and average monthly precipitation using a Spearman's rank correlation coefficient (Zar 1999).

\section{RESULTS}

Captures and population size: A total of 176 specimens of D. tolteca were captured, tagged and released. October was the month with the greatest number of specimens captured $(\mathrm{n}=53)$. The number of captures was significantly higher $\left(\mathrm{t}_{14}=2.78, \mathrm{p}=0.031\right)$ during the rainy season $(n=145)$ than in the dry season $(n=31)$. The number of recaptured specimens was 11 $(6.2 \%)$, six males and five females (10 adults and one juvenile), all of which were recaptured only once (5.5 months in average between initial capture and recapture). The population size was estimated as 237 individuals, with an average trappability of $40 \%$. Trappability was from $0 \%$ (minimum extreme value) in October 2006, and in January and February 2007, to $100 \%$ in May 2006 and August 2007.

There was no significant correlation between the number of monthly captures and monthly precipitation $(\mathrm{Q}=0.44, \mathrm{p}=0.08)$ or between the number of captures and the average monthly temperature $(\varrho=0.11, \mathrm{p}=0.665)$. Other abundant species presents in the assembly were Sturnira ludovici $(\mathrm{n}=55)$, Glossophaga soricina $(\mathrm{n}=51)$, Centurio senex $(\mathrm{n}=51), S$. lilium $(\mathrm{n}=39)$ and Carollia sowelli $(\mathrm{n}=38)$.

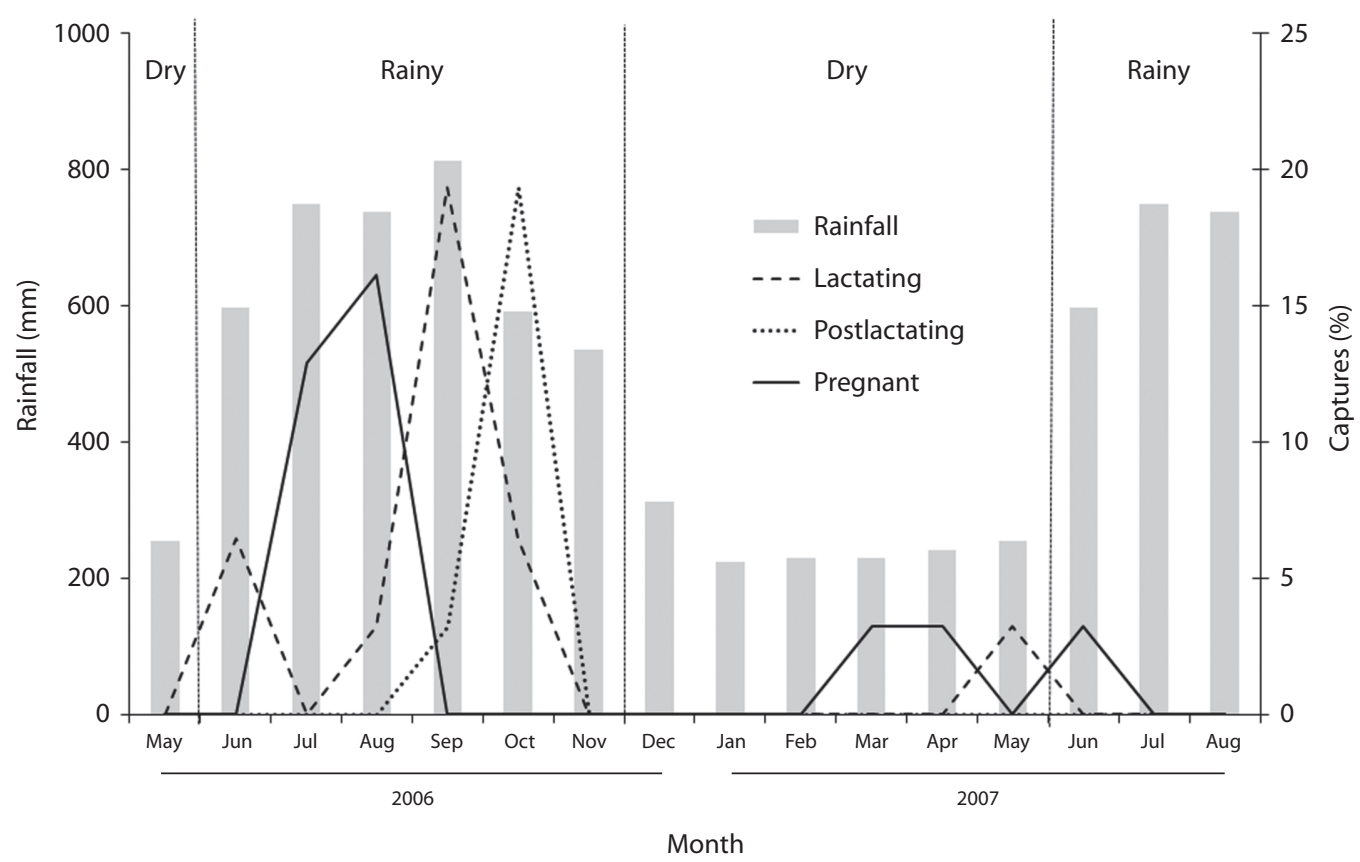

Fig. 1. Monthly activity of pregnant, lactating, and post-lactating females of Dermanura tolteca in a tropical forest of Mexico. 
Male-female ratio: A total of 98 females $(55.6 \%)$ and 78 males $(44.4 \%)$ were captured. The greatest number of specimens of both sexes was captured in October. The malefemale ratio of total captures was one male per 1.26 females, which did not differ significantly from a one-to-one ratio $(\mathrm{z}=1.43, \mathrm{df}=1, \mathrm{p}=0.15)$. During the dry season, the ratio was one male to 1.21 females $(\mathrm{z}=0.35, \mathrm{df}=1, \mathrm{p}=0.72$ ), and for the rainy season it was $1: 1.26(\mathrm{z}=1.32, \mathrm{df}=1$, $\mathrm{p}=0.18$ ).

Age structure: Adults accounted for the majority of the specimens captured, with 129 adults (73.3\%), followed by 42 sub-adults $(23.8 \%)$ and 5 juveniles (2.8\%). Significant differences in the monthly frequency of adults and sub-adults were observed $\left(\mathrm{t}_{15}=3.22, \mathrm{p}=0.050\right)$, as well as between adults and juveniles $\left(\mathrm{t}_{15}=3.51\right.$, $\mathrm{p}=0.030$ ), but not between the number of juveniles and that of sub-adults $\left(\mathrm{t}_{15}=1.71, \mathrm{p}=0.107\right)$. The group comprising adult males and adult females contained the greatest number of specimens (70 and 59, respectively), followed by sub-adult females $(\mathrm{n}=35)$, sub-adults male $(n=7)$ and 5 juveniles of both sexes (4 females and 1 male). The greatest number of adults was observed in August and October; the sub-adults were more common in September and October (Table 1). There were no significant differences in age structure between seasons (Mann-Whitney U-test $=1.09, \mathrm{p}=0.40$ ).

Reproduction: The majority of females were in a state of reproductive inactivity $(n=67$, $68.3 \%$ ). Lactating (11.2\%) and pregnant $(9.1 \%)$ females represented the greatest proportion of the active females in the rainy season of 2006, followed by post-lactating females $(7.1 \%)$. Active females were captured primarily in the rainy season, during September and October. Pregnant females were abundant in August; lactating and post-lactating females were more abundant in September and October, respectively. Fifty tree males $(67.9 \%)$ with no evidence of reproductive activity and 25 with scrotal testicles $(32.1 \%)$ were captured. Those belonging to the latter group were more frequently captured in September and October $(n=15)$.

Whereas reproductive activity was primarily concentrated in the rainy season of 2006 (August-September), this activity was rare during rainy season of 2007 and dry season (2006 and 2007) (Fig. 1). The presence of reproductively active female was significantly correlated with precipitation $(\varrho=0.51, \mathrm{p}=0.039)$. The presence of the greatest number of lactating females coincided with the months of the greatest precipitation (only 2006). There was no observed correlation between temperature and the number of females presenting evidence of reproductive activity ( $\mathrm{Q}=0.01, \mathrm{p}=0.940)$. In addition, there was no correlation between the number of males presenting evidence of reproductive activity and precipitation $(\mathrm{Q}=0.14$, $\mathrm{p}=0.591)$, or temperature $(\mathrm{Q}=0.03, \mathrm{p}=0.890)$.

Body mass: The average body mass of males was $18.17 \mathrm{~g}(\mathrm{SD}=2.45)$, and this differed significantly $\left(\mathrm{t}_{115}=2.206, \mathrm{p}=0.029\right)$ from that of females (mean $=19.10 \mathrm{~g}, \mathrm{SD}=1.90)$. No significant difference was observed in the monthly average body mass of males between seasons (Kruskal-Wallis $=0.026, \mathrm{df}=1, \mathrm{p}=0.870$ ); a similar result was observed for females (KruskalWallis $=0.409, \mathrm{df}=1, \mathrm{p}=0.522$ ). The average monthly body mass no differed between sexes (Kruskal-Wallis=3.408, $\mathrm{df}=1 \quad \mathrm{p}=0.064$ ). There was no observed correlation between the monthly index average and precipitation $(\mathrm{Q}=0.23, \mathrm{p}=0.445)$, nor temperature $(\mathrm{Q}=0.01$, $\mathrm{p}=0.957$ ).

\section{DISCUSSION}

The use of nylon cable ties as tags proves to be a promising option. Some commonly used devices present problems: whereas metal and plastic bands placed on the wings (Herreid et al. 1960, Kunz 1996, Baker et al. 2001, Dietz et al.2006) cause severe damage in the forearm of bats, the collars with metal balls produce skin irritation (Kunz 1996). Unlike the latter, which most resemble the devices used in this study, the use of nylon cable ties did not leave 


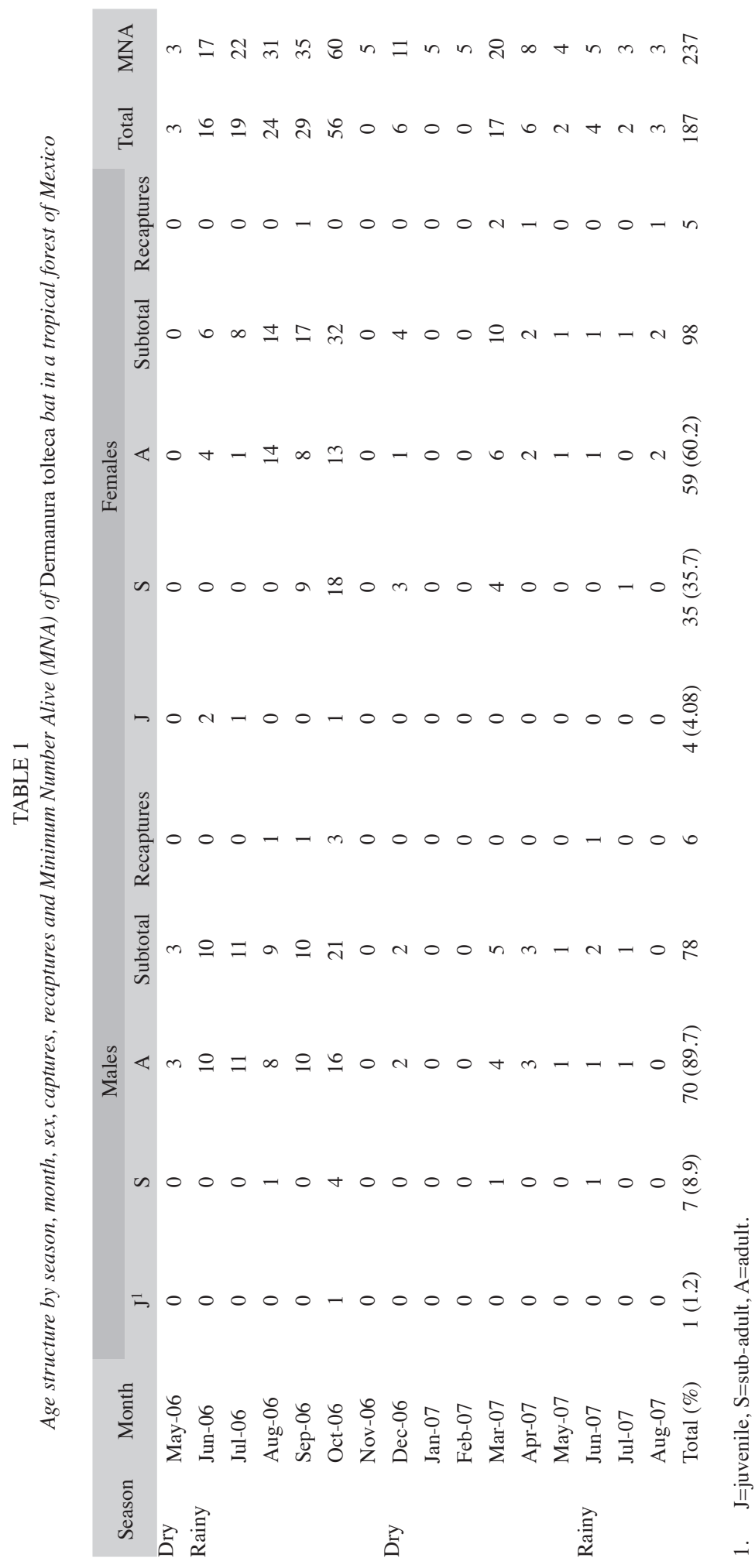


recaptured specimens with visible lesions that might be explained by the use of tags. In addition, the nylon cable ties are practical, available and inexpensive (Gannon 1993, Gannon \& Willig 1998).

The low number of captures and recaptures in this study is typical in many species of noseleaf bats captured with mist nets (Heithaus et al. 1975, Gardner et al. 1991, O'Shea et al. 2004). For example, the recapture rate of Dermanura phaeotis was 4.2\%, Artibeus jamaicensis $14.2 \%$ (Heithaus et al. 1975), Glossophaga soricina $11.6 \%$, D. phaeotis $23.5 \%$ (RamírezPulido \& Armella 1987), and Leptonycteris curasoae 2.2\% (Galindo et al. 2004). However, considerable variation occurs between populations of the same species; for example, $A$. lituratus has a range of 5.8\%-9.6\% (RamírezPulido \& Armella 1987) and 20\% of recapture rates (Gardner et al. 1991).

The correlation between captures and precipitation can be explained by fructification in the rainy season of several species of plants that are food for many nose-leaf bats, including D. tolteca (Opler et al. 1976). Dinerstein (1986) found that the largest captures of $D$. tolteca were obtained during the fructification months of many plants consumed by this species. A similar pattern has been observed in $D$. phaeotis and seven other species of nose-leaf bats (Heithaus et al. 1975). This observation is reinforced by the fact that capture probability rates are lower during the dry season than the rainy season. Capture probabilities can reflect the mobility of organisms (Santos-Moreno et al. 2007) associated with lower availability of fruit. On the other hand, the lack of correlation between the number of captures and temperature confirms a pattern observed in other studies: in nose-leaf bats, temperature is not a determining factor for activity or reproductive patterns, unlike what happens with bats of temperate or boreal habitats (Erkert 1982, Racey 1982).

Results obtained in this study corroborate those of other studies, as the population size of D. tolteca is consistently low throughout its area of distribution in Mexico (Iñiguez-Dávalos
1993, Navarro \& León-Paniagua 1995, Stoner 2002, Briones-Salas et al. 2004, García-García \& Santos-Moreno 2008), especially to the extent that estimated population sizes of other bat species of Phyllostomidae family are taken into consideration, such as Artibeus jamaicensis (3 800 to 4500 individuals, Leigh \& Handley 1991) and Leptonycteris curasoae (5 000 to 75000 individuals, Ceballos et al. 1997, Galindo et al. 2004).

Dermanura tolteca and other species, members of the subfamily Stenodermatinae, such as D. phaeotis, D. watsoni, A. jamaicensis and $U$. bilobatum form small roost colonies in shelters constructed with leaves from plants (Timm 1987, Gardner et al. 1991, Lewis 1995, Kunz \& McCracken 1996, McCracken \& Wilkinson 2000, Chaverri \& Kunz 2006). These specific roost-site requirements could limit the presence of large populations of this species, as observed in D. phaeotis and D. watsoni (Kunz \& McCracken 1996, Chaverri \& Kunz 2006). In addition, the effects of habitat disturbance and destruction are likely to be more significant in terms of population for species that use this type of roost than for other species of nose-leaf bats (Lewis 1995, Kunz \& McCracken 1996, Chaverri \& Kunz 2006).

A greater proportion of females than males were registered, but those differences were not significant, even throughout seasons. This may be due to the formation of small harems and polygynous groups with little allegiance to roost sites constructed from leaves (Fleming et al. 1972, Wilson 1979, Dinerstein 1986, Timm 1987, Iñiguez-Dávalos 1993), which has also been observed in other species of Stenodermatines, such as A. jamaicensis (Kunz et al. 1983, Ortega \& Arita 1999), a species on which studies have not shown a numerically dominant sex in regards to male-female ratio either.

The population is composed primarily of adults. This has been observed in other species of nose-leaf bats, such as A. jamaicensis (Kunz et al. 1983), Leptonycteris curasoae (Galindo et al. 2004) and L. nivalis (Moreno-Valdez et al. 2004). This may be explained in two ways: adults may be more prone to capture, 
as observed in Carollia perspicillata and A. jamaicensis (Fleming 1988, Gardner et al. 1991), which, in turn, could be due to a greater foraging range and overall mobility (Fenton \& Kunz 1977, Handley et al. 1991); or it could be due to a low survival adults rate, as reported in studies on A. jamaicensis (Gardner et al. 1991). The increase in the number of juvenile and sub-adult specimens in the rainy season observed in D. tolteca is consistent with that found in other species of nose-leaf bats, such as C.perspicillata (Fleming et al. 1972) and A. jamaicensis (Gardner et al. 1991).

The bimodal polyestrous reproductive pattern observed in $D$. tolteca coincides with that observed for this species in other studies (Fleming 1972, Wilson 1979, Dinerstein 1986, Timm 1987, Iñiguez-Dávalos 1993), and is common in many frugivorous bats of the Phyllostomidae family, such as A. jamaicensis, $A$. lituratus, D. watsoni, D. phaeotis, U. bilobatum, Sturnira lilium, Carollia perspicillata, Glossophaga soricina and Platyrrhinus helleri (Fleming 1972). This reproductive pattern is characterized by two estrous cycles a year, one at the beginning of the rainy season (MarchApril) and other at the end (July-August) (Hill \& Smith 1984).

In the studied population, the first gestation period occurred in the middle of the rainy season, between August and September. Despite not having found lactating females in the dry season, pregnant females were observed in March and April. It is likely that the second period of gestation occurs between the end of the dry season and the beginning of the rainy season (between April and June). This has also been reported in studies on D. tolteca at Sierra de Manantlán, Jalisco, Mexico (Iñiguez-Dávalos 1993) and Costa Rica (Dinerstein 1986).

The correlation between the number of females showing reproductive activity and precipitation confirms the hypothesis (proposed in other studies) that birth and lactation periods are synchronized with the rainy season and, therefore, with the fructification period of many plants (mainly of Ficus spp. and Solanum spp.) (Fleming 1972, Dinerstein 1986). In tropical regions, the fructification of many plants is seasonal, and the abundance of frugivorous nose-leaf bats is influenced by the presence of food resources, the dynamics of this situation determine the majority of ecological processes in relation to bats (Janzen 1967, Heithaus et al. 1975, Hernández-Conrique et al. 1997).

Females were found to be heavier than males. This difference has been observed in several species (Speakman \& Thomas 2003) and has been attributed to greater expenditures of energy needed to support the increased weight during pregnancy; this due to the transportation of fruit or offspring to roost sites (Speakman \& Thomas 2003, Galindo et al. 2004, Moreno-Valdez et al. 2004). Seasonal changes in the body weight of $D$. tolteca were not observed, contrary to those observed in $C$. perspicillata, L. nivalis and L. curasoae, perhaps as a result of the variation in the availability of food resources (Fleming 1988, Ceballos et al. 1997, Moreno-Valdez et al. 2004).

\section{ACKNOWLEDGMENTS}

The Consejo Nacional de Ciencia y Tecnología de México (CONACyT) gave a grant for Master of Science studies for J.L. GarcíaGarcía, and the Instituto Politécnico Nacional of México provided financial support for the project (grants CGPI-20070826 and SIP20080431 to AS-M). We appreciate the facilities provided by the authorities of Municipio Santiago Comaltepec to carry out the project. J. Arroyo-Cabrales, A. Castro-Campillo and G. Ramos provided valuable comments and suggestions to improve this work. M. Gonzales translated this document to the English language for publication.

\section{RESUMEN}

El murciélago Dermanura tolteca presenta una amplia distribución geográfica en México y es un importante dispersor de semillas de una variedad de plantas neotropicales. Sin embargo la información biológica sobre este murciélago es escasa, especialmente en aspectos demográficos. El objetivo de este trabajo fue documentar la dinámica poblacional y varios aspectos ecológicos de la especie. El 
trabajo fue conducido entre mayo 2006 y agosto 2007 en un bosque tropical perennifolio en el estado de Oaxaca, sureste de México, durante 80 noches, con un esfuerzo de muestreo total de $73200 \mathrm{~m}^{2}$ de red-hora. Se capturaron 187 individuos, 98 hembras y 78 machos. Se estimó el tamaño poblacional en 237 individuos, con un mayor número en la época lluviosa. Las capturas están correlacionadas con la precipitación mensual y este fenómeno puede estar ligado a la abundancia del recurso alimenticio en zonas tropicales y subtropicales. La proporción de sexos y la estructura de edad son las típicas de varios murciélagos filostómidos. El patrón de reproducción fue del tipo poliestrica bimodal, con periodos de nacimiento entre agosto-septiembre y abril-junio. Las hembras muestran mayor peso corporal que los machos. Es posible que este murciélago presente una baja densidad comparada con la de otros murciélagos filostómidos en todo su rango de distribución en México.

Palabras claves: Phyllostomidae, tamaño poblacional, poliestría, captura-recaptura, murciélagos, bosque tropical lluvioso, patrón reproductivo.

\section{REFERENCES}

Adler, G.H., M. Reich \& R.H. Tamarin. 1984. Demography of the meadow jumping mouse (Zapus hudsonius) in Eastern Massachusetts. Amer. Midl. Natur. 112: 387-391.

Arriaga, L., J.M. Espinoza, C. Aguilar, E. Martínez, L. Gómez \& E. Loa. 2000. Regiones Prioritarias Terrestres de México. Comisión Nacional para el Conocimiento y Uso de la Biodiversidad, Mexico.

Baker, G.B., L.F. Lumsden, E.B. Dettmann, N.K. Schedvin, M. Schulz, D. Watkins \& L. Jansen. 2001. The effect of forearm bands on insectivorous bats (Microchiroptera) in Aust. Wildlife Res. 28: 229-237.

Briones-Salas, M. \& V. Sánchez-Cordero. 2004. Mamíferos, p. 423-447. In A.J. García-Mendoza, M.J. Ordóñez \& M. Briones-Salas (eds.). Biodiversidad de Oaxaca. Instituto de Biología, UNAM-Fondo Oaxaqueño para la Conservación de la Naturaleza-World Wildlife Fund., Mexico.

Briones-Salas, M., V. Sánchez-Cordero \& A. Santos-Moreno. 2004. Diversidad de murciélagos en el gradiente altitudinal de la sierra Mazateca, Oaxaca, México, p. 65-74. In V. Sánchez-Cordero \& R.A. Medellín (eds.). Contribuciones mastozoológicas en homenaje a Bernardo Villa. Instituto de Biología e Instituto de Ecología, UNAM, Mexico.

Boyle, B.L. 1996. Changes on altitudinal and latitudinal gradients in Neotropical montane forest. Ph.D. Thesis, Washington University, USA.
Ceballos, G., J. Arroyo-Cabrales \& R. Medellín. 2005a. Lista sistemática de las especies, p. 73-95. In G. Ceballos \& G. Oliva (eds.). Los mamíferos silvestres de México. Comisión Nacional para el Conocimiento y Uso de la Biodiversidad y Fondo de Cultura Económica, Mexico.

Ceballos, G., J. Arroyo Cabrales, R. Medellín, L. Medrano \& G. Oliva. 2005b. Diversidad y conservación de Mamíferos de México, p. 21-95. In G. Ceballos \& G. Oliva (eds.). Los mamíferos silvestres de México. Comisión Nacional para el Conocimiento y Uso de la Biodiversidad y Fondo de Cultura Económica, Mexico.

Ceballos, G., T. Fleming, C. Chávez \& J. Nassar. 1997. Population dynamics of Leptonycteris curasoae (Chiroptera: Phyllostomidae) in Jalisco, Mexico. J. Mammal. 78: 1220-1230.

Chaverri, G. \& T.H. Kunz. 2006. Roosting ecology of the tent-roosting bat Artibeus watsoni (Chiroptera: Phyllostomidae) in southwestern Costa Rica. Biotropica 38: $77-84$.

Dietz, C., I. Dietz, T. Ivanova \& B.M. Siemers. 2006. Effects of forearm bands on horseshoe bats (Chiroptera: Rhinolophidae). Acta Chiropterol. 8: 523-535.

Dinerstein, E. 1986. Reproductive ecology of fruits bats and seasonality of fruit production in a Costa Rican cloud forest. Biotropica 18: 307-318.

Dirzo, R. \& M.C. García. 1992. Rates of deforestation in Los Tuxtlas, a Neotropical area in southeast Mexico. Conserv. Biol. 6: 84-90.

Dirzo, R. \& A. Miranda. 1991. El límite boreal de la selva tropical húmeda en el continente americano. Contracción de la vegetación y solución de una controversia. Interciencia 16: 240-247.

Efford, M. 1992. Comment-Revised estimates of the bias in the 'minimum number alive' estimator. Can. J. Zool. 70: 628-631.

Erkert, H.G. 1982. Ecological aspects of bat activity rhythms, p. 201-242. In T.H. Kunz (ed.). Ecology of bats. Plenum, New York, USA.

Espinoza-Medinilla, E., A. Anzures-Dadda \& E. CruzAldan. 1998. Mamíferos de la reserva de la biosfera El Triunfo, Chiapas. Rev. Mex. Mastozool. 3: 79-88.

Fenton, M.B. \& T.H. Kunz. 1977. Movements and behavior, p. 351-364. In R.J. Baker, J.K. Jones Jr. \& D.C. Carter (eds.). Biology of bats of the New World family Phyllostomiadae. Part II. Special Publications of the Museum of Texas Tech University, USA. 
Findley, J.S. 1993. Bats: A community perspective. Cambridge, Cambridge, England.

Fleming, T.H. 1988. The short-tailed fruit bat. University of Chicago, Chicago, USA.

Fleming, T.H. \& E.R. Heithaus. 1981. Frugivorous bats, seed shadows, and the structure of tropical forests. Biotropica 13: 45-53.

Fleming, T.H., E.T. Hooper \& D.E. Wilson. 1972. Three Central American bats communities: structure, reproductive cycles and movement patterns. Ecology 53: 555-569.

Gannon, M.R. 1993. A new technique for marking bats. Bat Res. News 34: 88-89.

Gannon, M.R. \& M.R. Willig. 1998. Long-term monitoring protocol for bats: Lessons from the Luquillo Experimental Forest of Puerto Rico, p. 271-291. In F. Dallmeier \& J. Comisky (eds.). Forest biodiversity in North, Central, and South America and the Caribbean: Research and Monitoring. The Parthenon, Cranforth, Lancashire, England.

Galindo, C.G., A. Sánchez, R.H. Quijano \& L.G. Herrera. 2004. Population dynamics of a resident colony of Leptonycteris curasoae (Chiroptera: Phyllostomidae) in central Mexico. Biotropica 36: 382-391.

García-García, J.L. \& A. Santos-Moreno. 2008. Diversidad de cuatro ensambles de murciélagos en San Miguel Chimalapa, Oaxaca, México, p. 411-326. In C. Lorenzo, E. Espinoza \& J. Ortega (eds.). Avances en el estudio de los mamíferos de México. Publicaciones especiales, Vol. II, Asociación Mexicana de Mastozoología, A.C. Mexico.

García-Mendoza, A.J. 2004. Integración del conocimiento florístico del estado, p. 305-325. In A.J. GarcíaMendoza, M.J. Ordóñez y M. Briones-Salas (eds.). Biodiversidad de Oaxaca. Instituto de Biología, UNAM-Fondo Oaxaqueño para la Conservación de la Naturaleza-World Wildlife Fund, Mexico.

Gardner, A.L., C.O. Handley Jr. \& D.E. Wilson. 1991. Survival and relative abundance, p. 53-75. In C.O. Handley Jr., D.E. Wilson \& A.L. Gardner (eds.). Demography and natural history of the common fruit bat, Artibeus jamaicensis, on Barro Colorado Island, Panamá. Smithsonian Contributions to Zoology 511.

Handley, C.O., JR. 1987. New species of mammals from northern South America: fruit-eating bats, genus Artibeus Leach, p. 163-172. In B.D. Patterson \& R.M. Timm (eds.). Studies in Neotropical mammalogy: essays in honor of Philip Hershkovitz. Fieldiana Zoology (NS) 39: 1-506.
Handley, C.O., Jr., D.E. Wilson \& A.L. Gardner.1991 (eds.). Demography and natural history of the common fruit bat Artibeus jamaicensis, on Barro Colorado Island, Panamá. Smithsonian Contributions to Zoology 511: iii + frontispiece +173 pp.

Heithaus, E.R., T.H. Fleming \& P.A. Opler. 1975. Foraging patterns and resource utilization in seven species of bats in a seasonal tropical forest. Ecology 56: 841854.

Hernández-Conrique, D., L.I. Iñiguez-Dávalos \& J.F. Storz. 1997. Selective feeding by Phyllostomid fruit bats in a subtropical montane cloud forest. Biotropica 29: $376-379$.

Herreid, C.F., R.B. Davis \& H.L. Short. 1960. Injuries due to bat banding. J. Mammal. 41: 398-400.

Hill, J.E. \& J.D. Smith. 1984. Bats, a natural history. University of Texas, Austin, USA.

Iñiguez-Dávalos, L.I. 1993. Patrones Ecológicos en la comunidad de murciélagos de la sierra de Manantlán, p. 355-370. In R.A. Medellín \& G. Ceballos (eds.). Avances en el estudio de los mamíferos de México. Asociación Mexicana de mastozoología A.C. Mexico.

Janzen, D.H. 1967. Synchronization of sexual reproduction of trees within the dry season in Central America. Evolution 21: 620-637.

Jones, J.K. \& D.C. Carter.1976. Annotated checklist, with keys to Subfamilies and Genera, p. 7-38, In R.J. Baker, J.K. Jones Jr. \& D.C. Carter (eds.). Biology of bats of the New World family Phyllostomiadae. Part I. Special Publications of the Museum of Texas Tech University, USA.

Krebs, C.J. 1966. Demographic changes in fluctuating populations of Microtus californicus. Ecol. Monogr. 36: 239-73.

Krebs, C.J. \& R. Boonstra. 1984. Trapability estimates for mark-recapture data. J. Zool. 62: 2440-2444.

Krebs, C.J. 1999. Ecological Methodology. Addison-Wesley, California, USA.

Kunz, T.H. 1996. Methods of marking bats, p. 304-310. In D.E. Wilson, J. Nichols, R. Rudrin, R. Cole \& M. Foster (eds.). Measuring and monitoring biological diversity standard methods for mammals. Smithsonian Institution, Washington D.C., USA.

Kunz, T.H. 2003. Censusing Bats: Challenges, Solutions, and Sampling Biases, p. 9-19. In T.J. O’Shea \& M.A. Bogan (eds.). Monitoring trends in bat populations of 
the United States and territories problems and prospects. U.S. Geological Survey, Biological Resources Discipline, Information and Technology Report, USGS/BRD/ITR-2003-0003, 274 p.

Kunz, T.H. \& G.F. McCracken. 1996. Tents and harems: apparent defense of foliage roosts by tent-making bats. J. Trop. Ecol. 12: 121-137.

Kunz, T.H., P.V. August \& C.D. Burnett. 1983. Harem social organization in cave roosting Artibeus jamaicensis (Chiroptera: Phyllostomidae). Biotropica 15: 133-138.

Kunz, T.H., C. Wemmer \& V. Hayssen. 1996. Sex, age and reproductive condition of mammals, p. 279-290. In D.E. Wilson, J. Nichols, R. Rudrin, R. Cole \& M. Foster (eds.). Measuring and monitoring biological diversity standard methods for mammals. Smithsonian Institution, Washington D.C., USA.

Lewis, S.E. 1995. Roost fidelity of bats: a review. J. Mammal. 76: 481-496.

Leigh, E.G. Jr. \& C.O. Handley Jr. 1991. Population estimates, p. 77-87. In C.O. Handley Jr., D.E. Wilson \& A.L. Gardner (eds.). Demography and natural history of the common fruit bat, Artibeus jamaicensis, on Barro Colorado Island, Panamá. Smithsonian Contributions to Zoology.

McCracken, G.F. \& G.S. Wilkinson. 2000. Bat mating systems, p. 321-362. In E.G. Crichton \& P.H. Krutzsch (eds.). Reproductive biology of bats. Academic, New York, USA.

Meave, J.A., A. Rincón \& M.A. Romero-Romero. 2006. The oak forests of the hyper-humid region of La Chinantla, Northern Oaxaca Range, Mexico, p. 113-125. In M. Kapelle (ed.). Ecology and Conservation of Neotropical Montane Oak Forests. Springer, USA.

Medellín, R.A. 1994. Mammals diversity and conservation in the Selva Lacandona, Chiapas, México. Conserv. Biol. 8: 780-799.

Mckelvey, K.S. \& D.E. Pearson. 2001. Population estimation with sparse data: the role of estimators versus indices revisited. Can. J. Zool. 79: 1754-1765.

Moreno-Valdez, A., R.L. Honeycutt \& W.E. Grant. 2004 Colony dynamics of Leptonycteris nivalis (mexican long-nosed bat) related to flowering agave in northern México. J. Mammal. 85: 453-459.

Morrison, D.W. 1978. Foraging ecology and energetics of the frugivorous bat Artibeus jamaicensis. Ecology 59: 716-723
Navarro, D. \& L. León-Paniagua. 1995. Community structure of bats along an altitudinal gradient in tropical eastern México. Rev. Mex. Mastozool. 1: 9-21.

Nichols, J.D. 1986. On the use of enumeration estimators for interspecific comparisons, with comments on a ‘trappability' estimator. J. Mamm. 67: 590-593.

Nichols, J.D. \& K.H. Pollock. 1983. Estimation methodology in contemporary small mammal capture-recapture studies. J. Mamm. 64: 253-260.

Ortega J. \& H. Arita. 1999. Structure and social dynamics of harem groups in Artibeus jamaicensis (Chiroptera: Phyllostomidae). J. Mammal. 80: 1173-1185.

O'Shea, T.J., L. Ellison \& R. Thomas. 2004. Survival estimation in bats: historical overview, critical appraisal, and suggestions for new approaches, p. 297-336. In W.L. Thompson (ed.). Sampling rare or elusive species. Island, Washington, Covelo, London.

Opler, P.A., G.W. Frankie \& H.G. Baker. 1976. Rainfall as a factor in the release, timing and synchronization of anthesis by tropical trees and shrubs. J. Biogeogr. 3: $231-236$.

Pocock, M.J.O., A.C. Frantz, D.P. Cowan, P.C.L. White \& J.B. Searle. 2004. Tapering bias inherent in minimum number alive (mna) population indices. J. Mamm. 85: 959-962.

Racey, P.A. 1982. Ecology of bat reproduction, p. 201-242. In T.H. Kunz (ed.). Ecology of bats. Plenum, New York, USA.

Ramírez-Pulido, J. \& M.A. Armella. 1987. Activity patterns of Neotropical bats (Chiroptera: Phyllostomidae) in Guerrero, Mexico. Southwest Nat. 32: 363-370.

Rzedowski, J. 1978. Vegetación de México. Limusa, Mexico.

Rzedowski, J. 1991. Diversidad y orígenes de la flora fanerógamica de México, p. 129-145. In T.P. Ramamoorthy \& R. Bye (eds.). Diversidad biológica de México. Orígenes y distribución. Instituto de Biología, UNAM, Mexico.

Rzedowski, J. \& R. Palacios-Chávez. 1977. El bosque de Engelhardtia (Oreomunnea) mexicana en la región de la Chinantla (Oaxaca, México): una reliquia del cenozoico. Bol. Soc. Bot. Mex. 36: 93-123.

Santos-Moreno, A., M. Briones-Salas \& R. López-Wilchis. 2007. Diferencias en algunos parámetros demográficos de Oryzomys chapmani (Rodentia: Muridae) asociadas a tres estados sucesionales de bosque 
mesófilo de montaña en Oaxaca, México. Acta Zool. Mex. 23: 123-137.

SEMARNAT-INEGI-UNAM, Secretaria de Medio Ambiente Recursos Naturales y Pesca (SEMARNAP), Instituto Nacional de Estadística, Geografía e Informática (INEGI) \& Universidad Nacional Autónoma de México (UNAM). 2000. Inventario Forestal Nacional 2000-2001. Escala 1:250 000. Instituto de Geografía, UNAM, Mexico.

Servicio Meteorológico Nacional (México). 2000. ERICK 2, base de datos meteorológico.

Simmons, N.B. 2005. Order Chiroptera, p. 312-529. In D.E. Wilson \& D.M. Reeder (eds.). Mammal species of the world: a taxonomic and geographic reference. Johns Hopkins University, Meryland, USA.

Speakman, J.R. \& D.W. Thomas. 2003. Physiological ecology and energetics of bats, p. 430-492. In T.H. Kunz \& M.B. Fenton (eds.). Bat Ecology. University of Chicago, USA.

Stoner, K.E. 2002. Murciélagos nectarívoros y frugívoros del bosque tropical caducifolio de la Reserva de Biosfera Chamela-Cuixmala, p. 379-395. In F.A. Noguera, J.H. Vega-Rivera, A.N. Garcia-Aldrete \&
M.Q. Avendaño (eds.). Historia natural de Chamela. Instituto de Biología, UNAM, Mexico.

Straube, F.C. \& G.V. Bianconi. 2002. Sobre a grandeza e a unidade utilizada para estimar esforço de captura com utilização de redes-de-neblina. Chiroptera Neotropical 8: 150-152.

Timm, R.M. 1987. Tent construction by bats of the genera Artibeus and Uroderma, p. 187-212. In B.D. Patterson \& R.M. Timm (eds.). Studies in Neotropical Mammalogy: essay in Honor of Philip Hershrovitz. Field. Zool. 39: 187-212.

Watkins, L.C., J.K. Jones Jr. \& H.H. Genoways. 1972. Bats de Jalisco, Mexico. Special Publication of the Museum of Texas Tech University, USA. 1: 1-44.

Webster, W.D. \& J.K. Jones Jr. 1982. Artibeus toltecus. Mammal. Spec. 178: 1-3.

Wilson, D.E. 1979. Reproduction patterns, p. 317-378. In R.J. Baker, J.K. Jones Jr. \& D.C. Carter (eds.). Biology of bats of the New World family Phyllostomiadae. Part III. Special Publications of the Museum of Texas Tech University, USA.

Zar, H.H. 1999. Biostatistical analysis. Prentice Hall, Upper Saddle River, New Jersey, USA. 